\title{
INSECTICIDAL PROPERTIES OF SOME PLANT EXTRACTS AGAINST COTTON LEAFWORM Spodoptera littoralis (BOISD)
}

\author{
Ragaa A. Sayed ${ }^{*}$; H.M. Mahfouz ${ }^{2}$; M.M. Ali ${ }^{1}$ and M.N. El-Basiony ${ }^{2}$ \\ 1. Inst. Plant Prot. Res., Cent. Agric. Res., Egypt. \\ 2. Dept. Plant Prod., Fac. Environ. Agric. Sci, Arish Univ., Egypt.
}

\begin{abstract}
Laboratory experiments were conducted under controlled conditions to test the insecticidal activity of aqueous and organic extracts of different solvents (ethanol and acetone) of nine plants collected from North-Sinai (Mint,Menth piperita L.; Clove, Syzygium aromaticum L.; Camphor, Cinnamomum camphora L.; Tree tobacco, Nicotiana glauca G.; Syrian Rue, Peganum harmala L.; Artemisia monosperma L.; Chinaberry, Melia azedarach L.; Egyptian henbane,Hyoscyamus muticus L. and Calotropis, Calotropis procera L.) against $4^{\text {th }}$ instar larvae of cotton leafworm (Spodoptera littoralis Boisd).The results showed that the aqueous extracts $C$. camphora $\mathrm{L}$. gave the highest toxicity among all tested plants with $\mathrm{LD}_{50}$ equal to $152 \mathrm{ppm}$ and M.piperita L. recorded the lowest toxicity with $\mathrm{LD}_{50}$ equal to $500 \mathrm{ppm}$. The toxicity index (T.I) was the highest value (100) in case of C.camphora L. and the lowest value was (30.6) in case of $M$. piperita L. The relative potency (R.P) showed the highest value equal to 327.2 with C.camphora $\mathrm{L}$, while the M.piperita $\mathrm{L}$. showed the lowest value equal to (100). In case of using organic (ethanol alcohol) extracts the results showed that the ethanolic extracts of S.aromaticum L. has the highest toxicity with $\mathrm{LD}_{50}$ equal to $76.9 \mathrm{ppm}$ and that of C.procera $\mathrm{L}$. has the lowest toxicity with $\mathrm{LD}_{50}$ equal to $205.6 \mathrm{ppm}$. The toxicity index (T.I) of S.aromaticum L. have the highest value (T.I) (100) and the C.procera have the lowest value T.I (37.4). The relative potency (R.P) was the highest in S.aromaticum L. (267.4) and the lowest (R.P) was in C.procera (100) .Finally by applying the organic (acetonic) extracts, the results, showed that acetonic extracts of S.aromaticum L. recorded the highest toxicity with $\mathrm{LD}_{50}$ equal to $44.4 \mathrm{ppm}$ while acetonic extracts of C.procera L. showed the lowest toxicity with $\mathrm{LD}_{50}$ equal to $100.6 \mathrm{ppm}$. The highest (T.I) was with S.aromaticum L. value (100) and the lowest (T.I) was observed in case of C.procera (44.1) recoded. The relative potency (R.P). Was the highest in case of S.aromaticum L.(226.6), while the lowest (R.P) was in case C.procera (100).
\end{abstract}

Key words: Insecticidal activity, natural plants, $4^{\text {th }}$ instar and larva cotton leafworm.

\section{INTRODUCTION}

In a number of African countries the cotton is an important economic crop including; Egypt - Sudan - Chad - Mali Tanzania - Zimbabwe and South Africa. On average, a cotton farmer loose at least one bale out of eleven bales/year due to insects damage and plant diseases. The development of chemical pesticides urge farmers to abandon most of conventional control strategies, mean wile an over reliance on the use of chemical show problems of resistance and or environmental pollution. (Mesbah et al. 2007). Currently the use of natural products instead of synthetic insecticides is of interest to overcome the pest resistance, reduce cost of pest control and minimize the environmental risk of different chemical

\footnotetext{
* Corresponding author: Tel.: +201227655804

E-mail address: dr.ragaa73@gmail.com
} 
groups of pesticides. The present study was conducted to evaluate the efficiency of using aqueous and organic extracts of some promising plants in controlling cotton leafworm Spodoptera littoralis (Boisd) in a laboratory study in an attempt to avoid the excess use of synthetic insecticides in environment.

\section{MATERIALS AND METHODS}

\section{Rearing the Tested Insect}

The cultured of cotton leafworm, Spodoptera littoralis (Boisd), used in this study originated from egg masses obtained from susceptible strain established in the laboratory of Environment Protection Department Faculty of Environmental Agricultural Sciences, Arish University, AlArish, North Sinai, Egypt. The progency of the insects together with occasional fresh supplies of egg formed the basis of culture designed to provide insects used in the present investigation. Five replicates per each conc., were used and 50 larvae/ Treatment. The $4^{\text {th }}$ instar larvae were used in the bioassay tests. Under laboratory conditions of $25 \pm 2 \mathrm{C}^{\mathrm{o}}$ (temperature) and $60 \pm 5 \%$ RH (Relative Humidity) El-Defrawi et al. (1964).

\section{Collection and identification of tested plants}

The following plants were used in the present study; Menth piperita L, Syzygium aromaticum L., Cinnamomum camphora L. Nicotiana glauca G.; Peganum harmala; Calotropis procera; Melia azedarach L.; Hyoscyamus muticus and Artemisia monosperma. Plant samples were collected from the area surrounding Arish Airport. Identification of the tested plants was based mainly on the taxonomic characters described by Boulos and El-Hadidi (1984) and revised through personal communication with Dr. Hameda Bedir (Professor of Botany Faculty of Science Arish University). Plant samples (Table1) were air dried for 24 weeks until complete dryness. Then these plants were milled in an electric grinder into fine powder and stored until used.

\section{Aqueous and organic extraction}

Ten grams of each dried plant part Table 1 was soaked in a dark flask containing 100 $\mathrm{ml}$ of aqueous and or organic extracts i.e Solvents used (Dist. $\mathrm{H}_{2} \mathrm{O}$ - ethyl alcohol and acetone) for the aqueous and organic extraction of each sample and allowed to stand for $24 \mathrm{hr}$. The extract was filtered by a Büchner funnel and that filtrate represents the aqueous and organic extract for each sample. These original crud extracts (organic and aqueous) were freshly prepared and considered as stock solution to be used as it is and by a series of successive dilutions to gain the tested concentration to be applied in bioassay.

\section{Bioassay tests for each organic or aqueous extracts}

A series of concentrations prepared from aqueous and organic extracts (ethanol alcohol and acetone) as following: 25, 50, $75,100,125$, and 250, 500, 750 and 1000 ppm to be used in the bioassay. For the bioassay treatments, five jars each containing (10) $4^{\text {th }}$ instar larvae of the tested insect, and each larva was topically treated with 1ul with the micro-applicator Mc.Cloud $\boldsymbol{e t}$ al. (1988). Five replicates were used for each treatment or concentration including the control. Average percentage mortality was recorded for each treatment $24 \mathrm{~h}$. for $120 \mathrm{hr}$. $\mathrm{LD}_{50}$ values and the corresponding slopes were obtained from the regression lines (Finney, 1971) and the confidence limits were computed using the normal equivalent deviate programmed. 
SINAI Journal of Applied Sciences (ISSN: 2314-6079) Vol. (6) Is. (2), Aug. 2017

Table (1): The list of plant species and their extract parts studied of tested plants.

\begin{tabular}{|c|c|c|c|c|c|}
\hline NO. & E. Name & Arabic name & Scientific name & Family & Part used \\
\hline 1 & Mint & 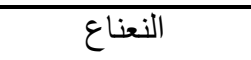 & Menth piperita $\mathrm{L}$. & Lamiaceae & Leaves \\
\hline 2 & Clove & ق قرنفل & Syzygiuma romaticum L. & Myrtaceae & Flowers \\
\hline 3 & Camphor & كافور & Cinnamomum camphora L. & Lauraceae & Leaves \\
\hline 4 & Tree Tobacco & مصاص الاخان & Nicotiana glauca $\mathrm{G}$. & Solanaceae & All plant \\
\hline 5 & Syrian Rue & الحرمـــل & Peganum harmala & Zygophyllaceae & Seeds \\
\hline 6 & Ader & العـــــــادر & Artemisia monosperma & Compositae & All plant \\
\hline 7 & Chinaberry & النيــــــم & Melia azedarach $\mathrm{L}$. & Meliaceae & Seeds \\
\hline 8 & Egyptian henbane & السكران المصري & Hyoscyamus muticus & Solanaceae & All plant \\
\hline 9 & Calotrpis & العشـــــار & Calotropis procera & Asclipiadaceae & Seeds \\
\hline
\end{tabular}

\section{RESULTS}

Acute toxicity of tested (aqueous) plant extracts against $4^{\text {th }}$ instar larvae of Cotton leafworm, Spodoptera littoralis (Boisd)

Results presented in Table 2 assure that the tested plants were arrayed in a descending order as following: (M. piperita, A. monosperma, H. muticus, N.glauca, $M$. azedarach, $C$. procera $S$. aromaticum, $P$. harmala and C. camphora), eliciting $\mathrm{LD}_{50}$ values arranged as following: (500, 361.1, $308.3,397.3,286.1,280.6,277.8,258.3$ and $152.8 \mathrm{ppm}$ ) respectively. The toxicity index of tested plants were arranged in a descending order as following: C.camphora L(100), P. harmala (59.2), S.aromaticum L.(55), C. procera (54.5), M. azedarach L. (53.9), N. glauca G. (51.4), H. muticus (49.6), A. monosperma (42.3) and $M$. piperita L. (30.6). The toxicity index (T.I) was the highest value (100) in case of $C$. camphora L. and the lowest value was (30.6) in case of $M$. piperita L. In the same attitude the relative potency (R.P) of the tested plants were arranged in a descending order as following: C.camphora L (327.2),
P.harmala (309.7), A.monosperma (221.5), S.aromaticum L.(180), C.procera (178.2), M.azedarach L. (174.8), N.glauca G.(168.2) and M. piperita L. (100). i.e (R.P) have the highest value equal to 327.2 with C.camphora $\mathrm{L}$ whil the $M$. piperita $\mathrm{L}$. showed the lowest value equal to (100).

Acute toxicity of tested organic (ethanolic) plant extracts against $4^{\text {th }}$ instar larvae of Cotton leafworm, Spodoptera littoralis (Boisd).

Results presented in Table 3 affirm that the tested plants were arranged in a descending order as following: (C. procera, N.glauca, M. azedarach, H.muticus, M. piperita, P.harmala, A.monosperma, C. camphora and $S$. aromaticum) anticipating that $\mathrm{LD}_{50}$ values arranged as in the following: (205.6, 143.1, 131.9, 125, 113.9, 103.1, 103.1, 88.9 and $76.9 \mathrm{ppm}$ ) respectively. The toxicity index (T.I) values were arranged in a descending order of the tested plants as following: S.aromaticum L.(100), C. camphora L. (86.6), P. harmala (74.6), A.monosperma (74.6), M. piperita L. (67.5), H. muticus (61.5), M. azedarach L. (58.3), N. glauca 
Table (2): Acute toxicity of tested (aqueous) plant extracts against $4^{\text {th }}$ instar larvae of Cotton leafworm, Spodoptera littoralis (Boisd).

\begin{tabular}{|c|c|c|c|c|c|c|}
\hline No. & Treatments & $\begin{array}{c}\mathbf{L D}_{50} \\
(\mathrm{ppm})\end{array}$ & Slope & $\begin{array}{c}\text { Confidence } \\
\text { limits of } \\
\text { LD }_{50}\end{array}$ & $\begin{array}{c}\text { Toxicity } \\
\text { index }\end{array}$ & $\begin{array}{l}\text { Relative } \\
\text { Potency } \\
\text { at(fold) }\end{array}$ \\
\hline 1 & Menth piperita L. & 500 & 0.421 & $357-706$ & 30.60 & 100 \\
\hline 2 & Syzygium aromaticum $\mathrm{L}$. & 277.8 & 0.547 & $205-374$ & 55 & 180 \\
\hline 3 & Cinnamomum camphora L. & 152.8 & 0.507 & $114-203$ & 100 & 327.20 \\
\hline 4 & Nicotiana glauca $\mathrm{G}$. & 297.3 & 0.516 & $212-420$ & 51.40 & 168.20 \\
\hline 5 & Peganum harmala & 258.3 & 0.598 & $190-353$ & 59.20 & 309.70 \\
\hline 6 & Artemisia monosperma & 361.1 & 0.467 & $178-350$ & 42.30 & 221.50 \\
\hline 7 & Melia azedarach L. & 286.1 & 0.533 & $201-406$ & 53.40 & 174.80 \\
\hline 8 & Hyoscya muticus & 308.3 & 0.503 & $220-434$ & 49.60 & 162.20 \\
\hline 9 & Calotropis procera & 280.6 & 0.542 & $206-382$ & 54.50 & 178.20 \\
\hline
\end{tabular}

$\mathrm{LD}_{50}$ values were calculated from the regression lines using method of Finney(1971).

Toxicity index according to Sun`s (1950)

Relative Potency at fold according to Zidan and Abd El-Megeed (1988).

Table (3). Acute toxicity of tested organic (ethanolic) plant extracts against $4^{\text {th }}$ instar larvae of cotton leafworm, Spodoptera littoralis (Boisd).

\begin{tabular}{clccccc}
\hline No. & Treatment & $\begin{array}{c}\text { LD } \\
\mathbf{p p m}\end{array}$ & Slope & $\begin{array}{c}\text { Confidence limits of } \\
\text { LD }_{\mathbf{5 0}}\end{array}$ & $\begin{array}{c}\text { Toxicity } \\
\text { index }\end{array}$ & $\begin{array}{c}\text { Relative } \\
\text { potency at } \\
\text { (fold) }\end{array}$ \\
\hline 1 & Menth piperita L. & 113.9 & 0.711 & $87.6-148.5$ & 67.5 & 180.5 \\
\hline 2 & Syzygium aromaticum L. & 76.9 & 0.566 & $64.98-91.13$ & 100 & 267.9 \\
\hline 3 & Cinnamomum camphora L. & 88.9 & 0.711 & $75.38-104.79$ & 86.6 & 231.3 \\
\hline 4 & Nicotiana glauca G. & 143.1 & 0.551 & $112.99-181.18$ & 53.7 & 143.7 \\
\hline 5 & Peganum harmala & 103.1 & 0.542 & $80.50-131.94$ & 74.6 & 199.4 \\
\hline 6 & Artemisia monosperma & 103.1 & 0.547 & $85.78-123.94$ & 74.6 & 199.4 \\
\hline 7 & Melia azedarach L. & 131.9 & 0.397 & $85.12-205.14$ & 58.3 & 155.9 \\
\hline 8 & Hyoscyamus muticus & 125 & 0.627 & $99.12-157.7$ & 61.5 & 164.5 \\
\hline 9 & Calotropis procera & 205.6 & 0.688 & $154.89-272.91$ & 37.4 & 100 \\
\hline
\end{tabular}

$\mathrm{LD}_{50}$ values were calculated from the regression lines using method of Finney(1971).

Toxicity index according to Sun`s (1950)

Relative Potency at fold according to Zidan and Abd El-Megeed (1988). 
G. (53.7) and C.procera (37.4). i.e. the S.aromaticum L. have the highest (T.I) was (100) and the C.procera have the lowest value T.I was (37.4). Also the relative potency (R.P) values were arranged in a descending order of the tested plants as in the following: S.aromaticum L. (267.4), C.camphora L (231.3), P. harmala (199.4), A.monosperma (199.4), M. piperita L. (180.5), H.muticus (164.5), M. azedarach L. (155.9), N.glauca G. (143.7) and $C$. procera (100), i.e the highest R.P was in S.aromaticum L.(267.4) and the lowest (R.P) was in C. procera (100).

Acute toxicity of tested organic (acetonic) plant extracts against $4^{\text {th }}$ instar larvae of cotton leafworm, Spodoptera littoralis (Boisd)

Results presented in Table 4 illustrat that the tested plants were arranged in a descending order as: (C. procera, $N$. glauca, M. azedarach, H.muticus, M. piperita, A. monosperma, $P$. harmala,
C.camphora and S.aromaticum) possessing that $\mathrm{LD}_{50}$ values arranged as following: (100.6, 87.7, 84.3, 83.3,82.5, 77.8, 62.2, 51.9 and $44.4 \mathrm{ppm})$ respectively. The toxicity index (T.I) showed an arrangement in a descending order as following: $S$. aromaticum L.(100), C.camphora L (85.5), P.harmala (71.4), A.monosperma (57.1), M. piperita L. (53.8), H.muticus (53.3), M.azedarach L. (52.4), N.glauca G. (50.6) and C.procera (44.1). i.e. the highest (T.I) was with S.aromaticum L. (100) and the lowest (T.I)was in case of C.procera value (44.1). The relative potency (R.P) also showed a similar trend i.e the arranged in a descending order as in the following: S.aromaticum L.(226.6), C.camphora L (193.8), P. harmala (161.7), A.monosperma (139.3), M. piperita L. (122), H. muticus (120.8), M. azedarach L. (118.8), N. glauca G. (114.6) and C.procera (100). i.e the highest value of R.P was in case of S.aromaticum L. (226.6), also the lowest (R.P) was in case C. procera (100).

Table (4): Acute toxicity of tested organic (acetonic) plant extracts against $4^{\text {th }}$ instar larvae of cotton leafworm, Spodoptera littoralis (Boisd).

\begin{tabular}{llccccc}
\hline No. & \multicolumn{1}{c}{ Treatment } & $\begin{array}{c}\mathbf{L D}_{\mathbf{5 0}} \\
\mathbf{p p m})\end{array}$ & Slope & $\begin{array}{c}\text { Confidence limits of } \\
\mathbf{L D}_{\mathbf{5 0}}\end{array}$ & $\begin{array}{c}\text { Toxicity } \\
\text { Index }\end{array}$ & $\begin{array}{c}\text { Relative } \\
\text { potency at } \\
\text { (fold) }\end{array}$ \\
\hline 1 & Menth piperita $\mathrm{L}$. & 82.5 & 0.488 & $67.9-103.98$ & 53.8 & 122 \\
\hline 2 & Syzygium aromaticum $\mathrm{L}$. & 44.4 & 0.666 & $24-98$ & 100 & 226.6 \\
\hline 3 & Cinnamomum camphora L. & 51.9 & 0.566 & $36-83$ & 85.5 & 193.8 \\
\hline 4 & Nicotiana glauca G. & 87.8 & 0.719 & $74.82-102.96$ & 50.6 & 114.6 \\
\hline 5 & Peganum harmala & 62.2 & 0.727 & $49.93-77.56$ & 71.4 & 161.7 \\
\hline 6 & Artemisia monosperma & 77.8 & 0.547 & $60.90-99.33$ & 57.1 & 139.3 \\
\hline 7 & Melia azedarach $\mathrm{L}$. & 84.7 & 0.474 & $70.48-101.14$ & 52.4 & 118.8 \\
\hline 8 & Hyoscyamus muticus & 83.3 & 0.484 & $64.24-108.14$ & 53.3 & 120.8 \\
\hline 9 & Calotropis procera & 100.6 & 0.609 & $77.52-130.49$ & 44.1 & 100 \\
\hline
\end{tabular}

$\mathrm{LD}_{50}$ values were calculated from the regression lines using method of Finney(1971).

Toxicity index according to Sun's (1950)

Relative Potency at fold according to Zidan and Abd El-Megeed (1988). 


\section{DISCUSSION}

Finally, results showed that the mortality occurred, due to the presence of active ingredients found in the utilized plants which have potential insecticidal activities against the tested pest or organism. Also it can be declared that there are certain conc.'s of both aqueous and/or organic extracts of each plant and it could be named as an optimum and best concentrations (conc.), causing, the maximum effect. Also and besides the variation between each plant and its response and insect target sensitivity to the conc. 's applied and at each tested phase i.e the presence of polar and apolar compounds. So that it is offering a kind of physiological selectivity which occurred due to the differences in its mode of action, showing a variability in type of toxic materials, its conc. and its response. Also the role of genetic factors in elucidating different responses and reactions (Upitis et al., 1973) and Arnaud et al.(2005). Also by going after $\mathrm{LD}_{50}$ values, the differences between the resulted in aqueous and organic (ethanolic and acetonic) of each plant may be due to differences in morphological and physiological and metabolic responses in each pest and in pest species (Conyers By Bell 1996). By more focusing the organic extracts of the tested plants, $\mathrm{LD}_{50}$ values, also indicated that organic extracts of most tested plants were better than aqueous extracts. These results were in an agreement with Eldoksch et al. (1984), who found that $\mathrm{LD}_{50}$ values of organic extracts were more toxic than $\mathrm{LD}_{50}$ values of aqueous extracts. Also in the same time all the plant conc.'s (aqueous and organic) against the tested insect showed that mortality percentages increased by increasing of used conc. 's. Schmidt et al. (1997), showed that, high conc. 's of methanolic extrat of neem led to high mortality (\%) against S.littoralis and Agrotis ipsilon. Ultimately, it is appearing that all plant extracts (aqueous and organic) are affecting oxygen arrives inside the experimental body insect and that cause asphyxia and leading to death. Death (\%) is different with conc. 's, extract types, tested insect and tested plants El-Araby (2008), Sayed (2010) and El-Araby (2014). Mean while and by throwing more light, Bell et al. (1990) reported that the presence of socalled secondary metabolite compounds, which have no known function in photosynthesis, growth or other aspects of plant physiology, give plant materials or their extracts or anti-insect activity. Secondary metabolite compounds include alkaloids, terpenoids, phenolics, flavonoids, chromenes and other minor chemicals can affect insects in several different ways, they may disrupt major metabolic pathways and cause rapid death, act as attractants, deterrents, phagostimulants, antifeedants or mortality oviposition. They may retard or accelerate development or interfere with the life cycle of the insect in other ways. So that it can explain the high mortality by using such plants as potent insecticides (Lioyd, 1973; Huang; et al. 1997; Asgary et al. 2000; Wink et al. (2004). Also the high mortality $\%$ and toxicity effects of the previous tested plants may be due to variation in the type of active ingredients and its chemicals structure and their mode of action which well presented in their aqueous or organic extracts (Liu and Ho, 1999). In conclusion and by focusing on the nature and body composition of the tested insect, Rynolds (1987) reported that the insect cuticle is a layered structure and the functions of the cuticle that are most vulnerable to insecticidal action are mechanical. These properties of the cuticle stiffness, strength and hardness are largely due to the major part of the cuticle thickness. Cuticle is a composite material, made of proteins, lipids, phenolics and tannins. They confer chemical and mechanical stability to the cuticle by increasing the hydrophobicity and of the cuticle matrix. And by more focusing on the 
nature and composition of the membranes and its affect by the used extracts on these membranes, Hamburger and Hostellman (1991) reported that the drug affects integrity of membranes and localized these membranes due to its highly lipophilic nature. More over that the chemical characteristics of the effective compounds such as charge and polarity of natural compounds affecting rates of interchange especially across membranes and cuticles to determine whether it reaches that tissue or target at intoxicating conc.'s Gilby (1984). In the other side, where there is an increase of effective compounds in organic extract of all plants, although there are some compounds can be soluble in aqueous extracts for some plants and lethal effect that indicating these, plants have properties of the selectivity and sensitivity. Also there is a natural selection pressure has often negativity affect the other species, (Keeler and Tu 1991). Ultimately many group of chemicals having a diverse chemical structure, but that posses common biological effect such as killer, attractants, hormonal, stimulation of growth and behavior. And since biological function are normally very selective processes so, a group of chemicals having similar biological activities must have some feature of similarity in selectivity (Harborne, 1988) These ecological and physiological selectivity were appearing in all tested plants and insects (Wilkinson, 1976). Also Suffness and Douros (1982) defined the selectivity i.e it must be high to limit the No. of leads for follow-up evaluation and expressed about sensitivity i.e it must be high in order to detect the low conc. 's of active ingrediants of compounds. So from all what mentioned in the literatures and references are in an accommodation and assuming the obtained results in nearly all cases of the study .Appointing the effect of the different plant extractives (aqueous and organic) applied on tested insects. And bearing in mind new more safe and ecotoxicological attitudes and considerations, facing the pests and unfavorable impacts of traditional insecticides applied in the environment. All these results were in an agreement with a No. of early studies dealing not only with S.littoralis, but also with many pests. Also very recently studies by Sayed et al. (2010). Rawi et al. (2011), Boursier et al. (2011) and El-Araby et al. (2014), were in an agreement with the obtained results.

\section{REFERENCES}

Arnaud, L.; Lan, H.T.T.; Brostaux, Y. and Haubruge, E. (2005). Efficacy of diatomaceous earth formulations admixed with grain against populations of Tribolium castaneum, J. Stored Prod. Res., 41 (2): 121-130.

Asgary, S.; Naderi, G.H.; Sarrafzadegan, N.; Mohammadifard, N.; Mostafavi, S. and Vakili, R. (2000). Antihypertensive and antihyperlipidemic effects of Achillea wilhelmsii. Drugs Exp. Clin. Res., 26: 89-93.

Bell, A.E.; Fellows, L.E. and Simoonds, S.J. (1990). Natural products from plants for the control of insect pests. E. Hodgson and R.J. Kuhr, eds. Safer insecticide development and use. Marcel Dekker, USA.

Boulos, L. and El-Hadidi, M.N. (1984). The Weed Flora of Egypt. The American University in Cairo Press, 178.

Boursier, C.M.; Bosco, D.; Coulibaly, A. and Negre, M. (2011). Aretraditional neem extract preparations as efficient as a commercial formulation of agadirachtin A. Crop Prot., 30 (3): 318-322.

Conyers, S.T. and Bell, C.H. (1996). The effect on the mortality of adult Cryptolestes ferrugineus (Stephens) (Coleoptera: Cucujidae), Sitophilus granarius L. (Coleoptera: Curculionidae) and Oryzaephilus surinamensis (L.) 
(Coleoptera: Silvanidae) of interrupting low oxygen exposures with periods of elevated oxygen, J. Stored Prod. Res., 32 (3): 187-194.

El-Araby, R.E. (2014). Comparative Study of Biochemical and Ecotoxicological Effects Insecticides and Potential Alternatives on controlling stored grain pests Ph.D Thesis. Fac. Environ. Agric. Sci., Suez Canal Unvi., 218.

El-Araby, R.E. (2008). Studies on some wiled Botanicals and Natural Pesticides in North-Sinai MSc. Fac. Environ. Agric. Sci, Sues Canal Univ.

El-Defrawi, M.E.; Toppozada, A.; Mansour, N. and Zeid, M. (1964). Toxicological studies on the Egyptian cotton leafworm, Prodenia Litura L.Susceptibility of different Larval instars of Proteina to insecticides. J. Econ., 57: 591-593.

Eldoksch, H.A.; El-Shazly, A.M.; Macklad, M.F.; Tamer, F. and El-Sebae, A.H. (1984). Insecticidal, fungicidal and mammalian toxicity of some plant extracts from desert plants and other vegetable sources of testeds plants. J. Agric. Res., Tanta Univ. 10 (4).

Finney, D.J. (1971). Probit analysis, $3^{\text {rd }} \mathrm{Ed}$. Cambridge Univ. Press, Camb., England.

Gilby, A.R. (1984). Cuticle and insecticides. In Biology of the integument. Springervarlog, Berlin, 644-702.

Hamburger, M. and Hostellman, $K$. (1991). Bioactivity in plants: the link between photochemistry and medicine. Photochem., 30 (12) : 3864-3874.

Harborne, J.B. (1988). Recent advances in chemical ecology. Nat. Prod. Reports, 323-344

Huang, Y.; Tan, J.M. W.L.; Kini, R.M. and Ho, S.H. (1997). Toxic and antifeedant action of nutmeg oil against Tribolium castaneum $\mathrm{H}$. and Sitophilus zeamais M., J. Stored Prod. Res., 33 (4): 289-298.

Keeler, R.F. and Tu, A.T. (1991). Hand Book of Natural Toxins. 6: 1250.

Lioyd, C.J. (1973). The toxicity of pyrethrins and five synthetic pyrethroids, to Tribolium castaneum H., and susceptible and pyrethrin-resistant Sitophilus granarius L., J. Stored Products Res., 9 (2): 77-92.

Liu, Z.L. and Ho, S.H. (1999). Bioactivity of the essential oil extracted from Evodia rutaecarpa Hook $\mathrm{f}$. et Thomas against the grain storage insects, Sitophilus zeamais Motsch. and Tribolium castaneum H.J. Stored Products Res., 35 (4): 317 328.

Mc Cloud, T.E.; Nemec, J.; Muschik, G.; Sheffield, H.G.; Quesenberry, P.; Suffness, M.; Gragg, G. and Thampson, J. (1988). Extraction of bioactive molecules from plants, Int. Products Res, Park City, Utah, 17-21.

Mesbah, H.A.; Saad, A.S.A.,; Mourad, A.K.; Taman, F.A. and Mohamed, I.B. (2007). Joint action of Quercetin with four insecticides on The Cotton LeafWorm Larvae, Spodoptera littoralis Boisd. (LEp.: Noctuidae) In Egypt. Comm. Appl. Biol. Sci. Ghent Univ., 72 (3): 447-459.

Rawi, S.M.; Bakry, F.A. and Al-Hazmi, M.A. (2011). Biochemical and histopathological effect of extracts on Spodoptera littoralis Larvae. J. Evolutionary Biology. Res., 3(5): 67-78.

Rynolds, S.E. (1987). The cuticle, growth and moulting in insects: The essential background to the action of Acylurea. Insect.-Pest. Sci., 20: 131-146.

Sayed, R.A. (2010). New Environmental and Ecological Aspects in controlling pests. MSc. Thesis. Fac. Environ. Agric. Sci. Suez Canal Univ. 
Schmidt, G.H.; Ahmed, A.A.I. and Breuer, M. (1997). Effect of Melia azedarach extract on larval development and reproduction parameters of Spodoptera littoralis (Boisd). And Agrotisipsilon (Hufn). (Lep. Noctuidae). Anzeiger fur Schadlingskunde, Pflanzenschutz, Umweltschutz, 70 (1): 4-12.

Suffness, M. and Douros, J. (1982). Current status of the NCI plant and animal product, J. Nat. Prod., Res., 45 (1): 1-14.

Sun, Y.P. (1950). Toxicity index: an improved method of comparing the relative toxicity of insecticides. J. Econ. Entomol, 43: 45-53.

Wink, M.; El-Shazly, A.M. and Hafez, S.S. (2004). Comparative sudy of the essential oils and extracts of Achillea fragrantissima F. Sch. Bip. And Achillea santolina L. (Asteraceae) from Egypt. NCBI., J., 59 (3): 226-230.

Upitis, E.; Monro, H.A.U. and Bond, E.J. (1973). Some aspects of inheritance of tolerance to methyl bromide by Sitophilus granarius L., J. Stored Prod. Res., 9 (1): 13-17.

Wilkinson, C.F. (1976). Insecticides Biochemistry and physiology, Plenum press, N.Y. London, 768.

Zidan, Z.H. and M.I. Abd El-Megeed (1988). New approaches in pesticides and insect control. Arabic publishing House and Delivery, Cairo, 605 (Inarabic language). 


\section{الملخص العربي}

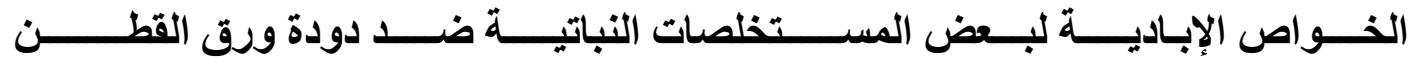

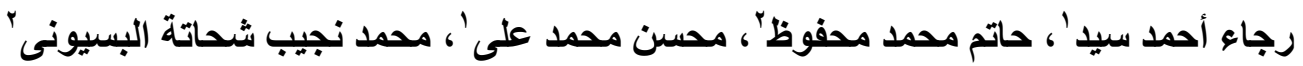

ا ـ قسم بحوث دودة ورق القطن، معهد بحوث وقاية النباتات، مركز البحوث الزر اعبة، مصر.

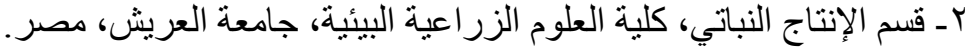

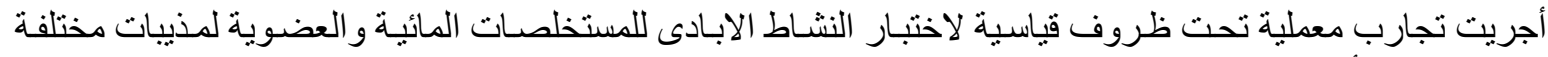

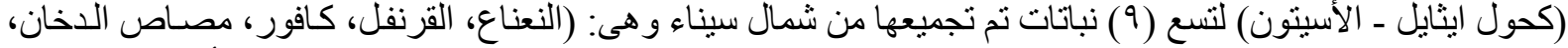

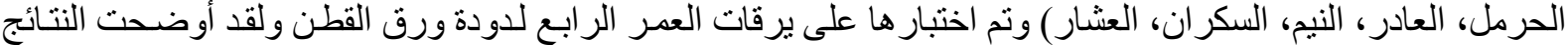

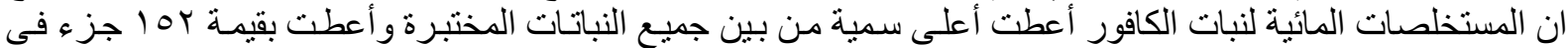

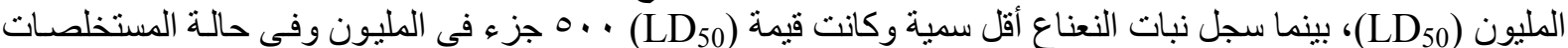

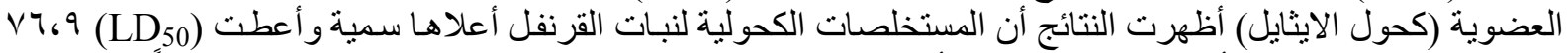

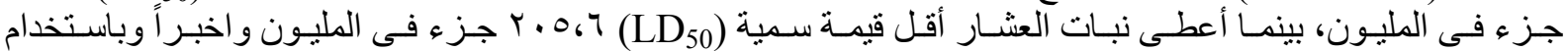

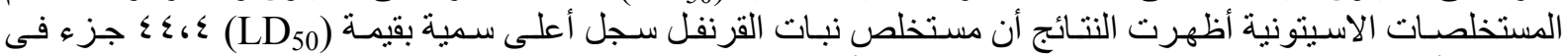

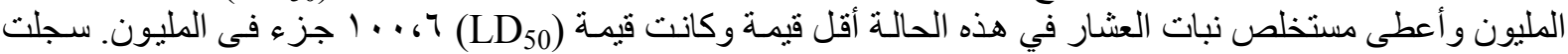

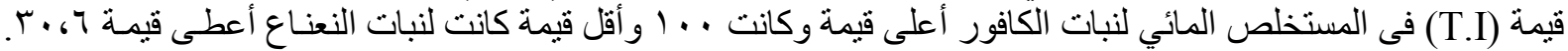

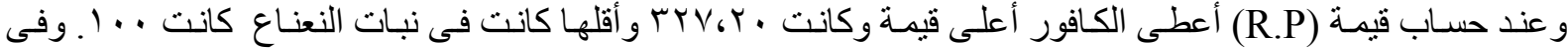

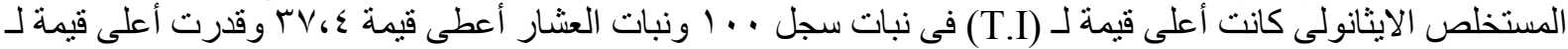

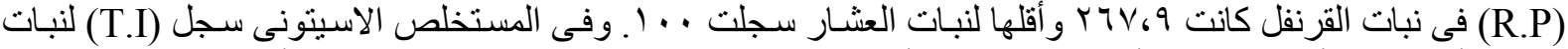

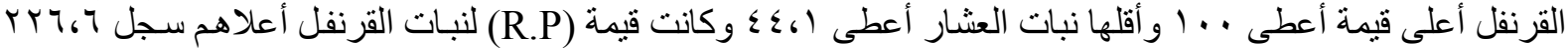

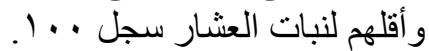
الكلمات الإسترشادية: المبيدات الفعالة، النباتات الطبيعية، الطور الر ابع، دودة ورق القطن. 